\title{
Yield, Quality Parameters and Economics of Sunflower (Helianthus annuus L.) as Influenced by Micronutrient Mixture Foliar Application
}

\author{
K. Narayana Rao*, E. Rajath, and Kirana Kumara \\ Department of Soil Science and Agricultural Chemistry, College of Agriculture, University of \\ Agricultural Sciences, Raichur, Karnataka, India \\ *Corresponding author
}

\begin{abstract}
A B S T R A C T
During the Kharif 2017, a field experiment was conducted to study the

Keywords

yield, micronutrient mixture, quality, foliar application

Article Info

Accepted:

15 December 2019

Available Online:

20 January 2020

effect of foliar application of micronutrient mixture on yield and quality parameters of sunflower at MARS, Raichur. Experiment was laid out in Randomized complete block design with three replications and nine treatments. Results revealed that foliar application of Grade I multi micronutrient mixture(Fe-2\%, Zn-3\%, Mn-1\% and B-0.5\%) @ $10 \mathrm{ml} \mathrm{L}^{-1}+$ soil application of RDF + Zinc sulphate @ $10 \mathrm{~kg} \mathrm{ha}^{-1}$ has recorded highest seed yield $\left(2243.34 \mathrm{~kg} \mathrm{ha}^{-1}\right)$, stalk yield $\left(3995 \mathrm{~kg} \mathrm{ha}^{-1,}\right)$ oil content $(35.37$ $\%$ ), oil yield (793.33 $\mathrm{kg} \mathrm{ha}^{-1}$ ), protein content (17.37\%),protein yield (389 $\mathrm{kg} \mathrm{ha}^{-1}$ ), gross returns (C.79290 ha ${ }^{-1}$ ), net returns $\left(\right.$ C.47740 ha ${ }^{-1}$ ) and B:C ratio (2.51).Hence it can concluded that foliar application of multi micronutrient mixture was economically feasible.
\end{abstract}

\section{Introduction}

Sunflower (Helianthus annuus L.) is an important oilseed crop in the world and ranks third next to groundnut and soybean in production. In India sunflower was introduced during 1972 and recently established as a potential oilseed crop of economic importance. By the virtue of its short duration, photo insensitive and wide adoptability to different agro climatic regions and soil types, it yields high quality oil in addition to its higher yield potential per unit area. Hence, sunflower is a promising oil seed crop in India. Sunflower seeds are highly nutritious it contains 14-19 per cent protein, 40-45 per cent oil, 21-27 per cent hull, 7-9 per cent soluble sugars and 30-35 per cent carbohydrates. The oil is considered to be a high quality due to its non-cholesterol properties. It contains 20-25 per cent and 4070 per cent of oleic acid and linoleic acid respectively. The linoleic acid helps in washing out cholesterol deposition in the 
coronary arteries of the heart, therefore, sunflower oil is recommended for the patients having heart problem. It contains sufficient amount of calcium, iron and vitamins like A, D, E and B complex. Sunflower oil is primarily used for cooking and is a major ingredient in some margarine and shortening products. (Muhammad Anjum et al., 2012)

Micronutrients are of growing importance in crop nutrition because of increased demand from higher yields of crops and intensive cropping, continued expansion of cropping and forestry on marginal land with low inherent levels of micronutrients. The increased use of high-analysis fertilizers containing low levels of micronutrients and decreased incorporation of manures, composts and crop residues to the soil.

The multi-micronutrients mixture facilitate the application of the wide range of plant nutrients in the proportion and to suit the specific requirements of a crop in different stages of growth, and are more relevant under site specific nutrient management practices. The low use efficiency of fertilizers, supplying nutrient, in large proportion can be improved by their modifications to lessen the negative aspects as well as trying to combine one or two more nutrients so that with the same application effort, crop benefits with multi-nutrient needs. Therefore, there is a need to promote balanced fertilization for which use of appropriate multi-micronutrient mixture grades would play a big role to improve nutrients use efficiency and enhance crops productivity for food and nutritional security.

\section{Materials and Methods}

The field experiment was conducted at MARS farm Raichur, during kharif 2017. Raichur is located in Zone-2 (North Eastern Dry Zone) of Karnataka at latitude, longitude and altitude of $16^{\circ} 15^{\prime} \mathrm{N}, 77^{\circ} 20^{\prime} \mathrm{E}$ and 389 meters above the MSL, respectively. Experiment was laid out in a Randomized Complete Block Design (RCBD) with nine treatments were replicated thrice, and hybrid used was KBSH-44.

\section{Treatment details}

\begin{tabular}{|l|l|}
\hline $\mathbf{T}_{\mathbf{1}}$ & RDF (NPK @ 90:90:60 and Gypsum @100 kg ha $\mathbf{~}^{\mathbf{- 1}}$ ) \\
\hline $\mathbf{T}_{\mathbf{2}}$ & $\mathrm{T}_{1}+\mathrm{ZnSO}_{4} @ 10 \mathrm{~kg} \mathrm{ha}^{-1}$ soil application \\
\hline $\mathbf{T}_{\mathbf{3}}$ & $\mathrm{T}_{1}+$ Foliar spray of Grade-1 micronutrient mixture @ $2.5 \mathrm{ml} \mathrm{L}^{-1}$ of water \\
\hline $\mathbf{T}_{\mathbf{4}}$ & $\mathrm{T}_{1}+$ Foliar spray of Grade-1 micronutrient mixture @ $5 \mathrm{ml} \mathrm{L}^{-1}$ of water \\
\hline $\mathbf{T}_{\mathbf{5}}$ & $\mathrm{T}_{1}+$ Foliar spray of Grade-1 micronutrient mixture @ $10 \mathrm{ml} \mathrm{L}^{-1}$ of water \\
\hline $\mathbf{T}_{\mathbf{6}}$ & $\mathrm{T}_{2}+$ Foliar spray of Grade-1 micronutrient mixture @ $2.5 \mathrm{ml} \mathrm{L}^{-1}$ of water \\
\hline $\mathbf{T}_{\mathbf{7}}$ & $\mathrm{T}_{2}+$ Foliar spray of Grade-1 micronutrient mixture @ $5 \mathrm{ml} \mathrm{L}^{-1}$ of water \\
\hline $\mathbf{T}_{\mathbf{8}}$ & $\mathrm{T}_{2}+$ Foliar spray of Grade-1 micronutrient mixture @ $10 \mathrm{ml} \mathrm{L}^{-1}$ of water \\
\hline $\mathbf{T}_{\mathbf{9}}$ & Absolute control \\
\hline
\end{tabular}

Note: 1. All the treatments received FYM @ $8 \mathrm{t} \mathrm{ha}^{-1}$ as common basal application except absolute control.

2. KSDA Grade-I Multi micronutrient mixture of Fe- $2.0 \%$, Zn- $3.0 \%$, Mn- $1.0 \%$ \& B- $0.5 \%$.

$3.75 \%$ Nitrogen is applied as basal and remaining $25 \%$ at 40 DAS.

4. Micronutrients mixture spray was done at 30, 45 and 60 DAS. 
The experimental soil was clay loam in texture with $\mathrm{pH}(1: 2.5)$ of 7.65 , EC $0.13 \mathrm{~d}$ $\mathrm{Sm}^{-1}$, organic carbon $4.6 \mathrm{~g} \mathrm{~kg}^{-1}$, available $\mathrm{N}$ $282 \mathrm{~kg} \mathrm{ha}^{-1}, \mathrm{P} 2 \mathrm{O} 531 \mathrm{~kg} \mathrm{ha}^{-1}, \mathrm{~K} 2 \mathrm{O} 319 \mathrm{~kg} \mathrm{ha}^{-}$ 1 , DTPA extractable $\mathrm{Fe}, \mathrm{Zn}, \mathrm{Mn}$ and $\mathrm{Cu}$ of $4.15,0.54,17.20$ and $0.94 \mathrm{mg} \mathrm{kg}^{-1}$ and hot water soluble B $0.89 \mathrm{mg} \mathrm{kg}^{-1}$. The multi micronutrient mixture (Grade I) was prepared as per Karnataka State Department of Agriculture recommendations consisting of Fe: $2.0 \%$, Mn: $1.0 \%, \mathrm{Zn}: 3.0 \%$ and B: 0.5 $\%$. This mixture was prepared in the laboratory by using iron sulfate, manganese sulfate, zinc sulfate and boric acid. The prepared mixture was preserved by adding a pinch of citric acid.

\section{Results and Discussion}

\section{Yield parameters}

Various yield attributing parameters were influenced by the foliar application of micronutrient mixture and are presented in Table 1. Highest number of seeds per head (758), test weight (5.59 $\mathrm{g})$, head diameter $(19.1 \mathrm{~cm})$ and seed weight per head $(40.38 \mathrm{~g})$ were recorded in treatment $\left(\mathrm{T}_{8}\right)$ with the application of $\mathrm{RDF}+\mathrm{ZnSO}_{4} @ 10 \mathrm{~kg} \mathrm{ha}^{-1}$ soil application + foliar spray of Grade-1 micronutrient mixture@10 ml L-1 of water@ 30,45 and 60 DAS.

But there was no significant difference observed with respect to number of unfilled seeds per head. Increase in various parameters was due to supplement of micronutrients which resulted higher number of leaves and leaf area index, indicates high mobilizable protein at the beginning of reproductive stage and boron spraying increased the number of filled seeds and increased translocation of photosynthates from vegetative sources towards the reproductive organs which helps the crop to put forth higher test weight. Increase in head diameter may be attributed to influence of sulphur combined with micronutrients improved growth through increased nutrient assimilation which in turn accelerated the crop to put forth larger heads. Increase in seed weight per headis due to increase in head diameter, number of seeds per head and test weight. Similar results were reported by Ramesh kumar (2008).

\section{Seed and stalk yield}

Highest seed and stalk yield was recorded by the treatmentT $\mathrm{T}_{8}$ RDF + FYM @ $8 \mathrm{t} \mathrm{ha}^{-1}+$ $\mathrm{ZnSO}_{4} @ 10 \mathrm{~kg} \mathrm{ha}^{-1}+$ foliar spray of micronutrient mixture @ 10 ml L ${ }^{-1}$ (2243 and $3995 \mathrm{Kg} \mathrm{ha}^{-1}$, respectively) and it is on par with the $\mathrm{T}_{5}$ : RDF + FYM @ $8 \mathrm{t} \mathrm{ha}^{-1}+$ foliar spray of micronutrient mixture @ $10 \mathrm{ml} \mathrm{L}^{-1}$ (2201 and $3959 \mathrm{~kg} \mathrm{ha}^{-1}$ ) (Table 1 and Fig. 1).

An increase in seed yield due to increase in yield components especially seed weight and higher seed setting, whereas increase in stalk yield is due to increased total dry matter accumulation. This is due to balanced supply of plant nutrients through application of RDF, FYM along with soil application of $\mathrm{ZnSO}_{4}$ @ $10 \mathrm{~kg} \mathrm{ha}$ and foliar application of micronutrient mixture @ $10 \mathrm{ml} \mathrm{L}{ }^{-1}$ attained healthy and vigorous growth of crop, more seed setting and increased seed weight.

These micronutrients involved in increased auxine biosynthesis, IAA production and protein synthesis, which helps in promoting vegetative growth and ultimately the yield. Similar results were reported by several workers like Ebrahimian and Ahmad (2011), Chowdhary et al., (2010) and kirana kumara et al.(2019) 
Table.1 Effect of foliar nutrition of micronutrient mixture on yield and yield parameters of sunflower

\begin{tabular}{|c|c|c|c|c|c|c|c|c|}
\hline $\begin{array}{c}\text { Treatme } \\
\text { nts }\end{array}$ & $\begin{array}{l}\text { No. of } \\
\text { seeds } \\
\text { head }^{-1}\end{array}$ & $\begin{array}{c}\text { No. of } \\
\text { unfilled } \\
\text { seeds }\end{array}$ & $\begin{array}{c}\text { Test } \\
\text { weight } \\
\text { (g) }\end{array}$ & $\begin{array}{c}\text { Head } \\
\text { diameter } \\
(\mathbf{c m})\end{array}$ & $\begin{array}{l}\text { Seed weight } \\
\text { head }^{-1}(\mathrm{~g})\end{array}$ & $\begin{array}{c}\text { Seed } \\
\text { yield } \\
\left(\mathrm{kg} \mathrm{ha}^{-1}\right)\end{array}$ & $\begin{array}{c}\text { Stalk yield } \\
\left(\mathrm{kg} \mathrm{ha}^{-1}\right)\end{array}$ & $\begin{array}{c}\text { Harvest } \\
\text { index } \\
(\%)\end{array}$ \\
\hline $\mathbf{T}_{1}$ & 725 & 166 & 4.95 & 14.80 & 35.72 & 1858 & 3784 & 32.94 \\
\hline $\mathbf{T}_{2}$ & 721 & 169 & 4.98 & 15.10 & 36.43 & 2023 & 3910 & 34.11 \\
\hline$T_{3}$ & 745 & 166 & 5.12 & 16.31 & 38.17 & 2120 & 3900 & 35.22 \\
\hline $\mathbf{T}_{4}$ & 747 & 162 & 5.27 & 17.12 & 38.67 & 2148 & 3922 & 35.39 \\
\hline$T_{5}$ & 750 & 165 & 5.38 & 17.34 & 39.63 & 2201 & 3959 & 35.73 \\
\hline$T_{6}$ & 746 & 162 & 5.12 & 17.00 & 38.41 & 2134 & 3958 & 35.03 \\
\hline $\mathbf{T}_{7}$ & 748 & 166 & 5.28 & 17.67 & 39.77 & 2186 & 3956 & 35.60 \\
\hline $\mathbf{T}_{8}$ & 758 & 159 & 5.59 & 19.10 & 40.38 & 2243 & 3995 & 35.96 \\
\hline$T_{9}$ & 708 & 166 & 4.19 & 12.33 & 32.44 & 650 & 2416 & 21.20 \\
\hline S.Em. \pm & 5.34 & 1.90 & 0.21 & 0.69 & 0.49 & 7 & 26. & 0.47 \\
\hline $\begin{array}{l}\text { C.D. @ } \\
5 \%\end{array}$ & 16 & NS & 0.62 & 2.08 & 1.48 & 22 & 78 & 1.41 \\
\hline
\end{tabular}

$\mathrm{T}_{1}$ : RDF (NPK @ 90:90:60 and Gypsum @ $100 \mathrm{~kg} \mathrm{ha}^{-1}$ ), $\mathrm{T}_{2}: \mathrm{T}_{1}+\mathrm{ZnSO}_{4} @ 10 \mathrm{~kg} \mathrm{ha}^{-1}$ soil application, $\mathrm{T}_{3}: \mathrm{T}_{1}+$ Foliar spray of Grade-1 micronutrient mixture @ $2.5 \mathrm{ml} \mathrm{L}^{-1}$ of water, $\mathrm{T}_{4}: \mathrm{T}_{1}+$ Foliar spray of Grade-1 micronutrient mixture@ $5 \mathrm{ml} \mathrm{L}^{-1}$ of water, $\mathrm{T}_{5}: \mathrm{T}_{1}+$ Foliar spray of Grade-1 micronutrient mixture @ $10 \mathrm{ml} \mathrm{L}^{-1}$ of water, $\mathrm{T}_{6}: \mathrm{T}_{2}+$ Foliar spray of Grade-1 micronutrient mixture @ $2.5 \mathrm{ml} \mathrm{L}^{-1}$ of water, $\mathrm{T}_{7}: \mathrm{T}_{2}+$ Foliar spray of Grade-1 micronutrient mixture @ $5 \mathrm{ml} \mathrm{L}^{-1}$ of, water, $\mathrm{T}_{8}: \mathrm{T}_{2}+$ Foliar spray of Grade-1 micronutrient mixture @ $10 \mathrm{ml} \mathrm{L}^{-1}$ of water, $\mathrm{T}_{9}$ :

Absolute control.

Note- Foliar sprayof micronutrient mixture was done at 30, 45 and 60 DAS.

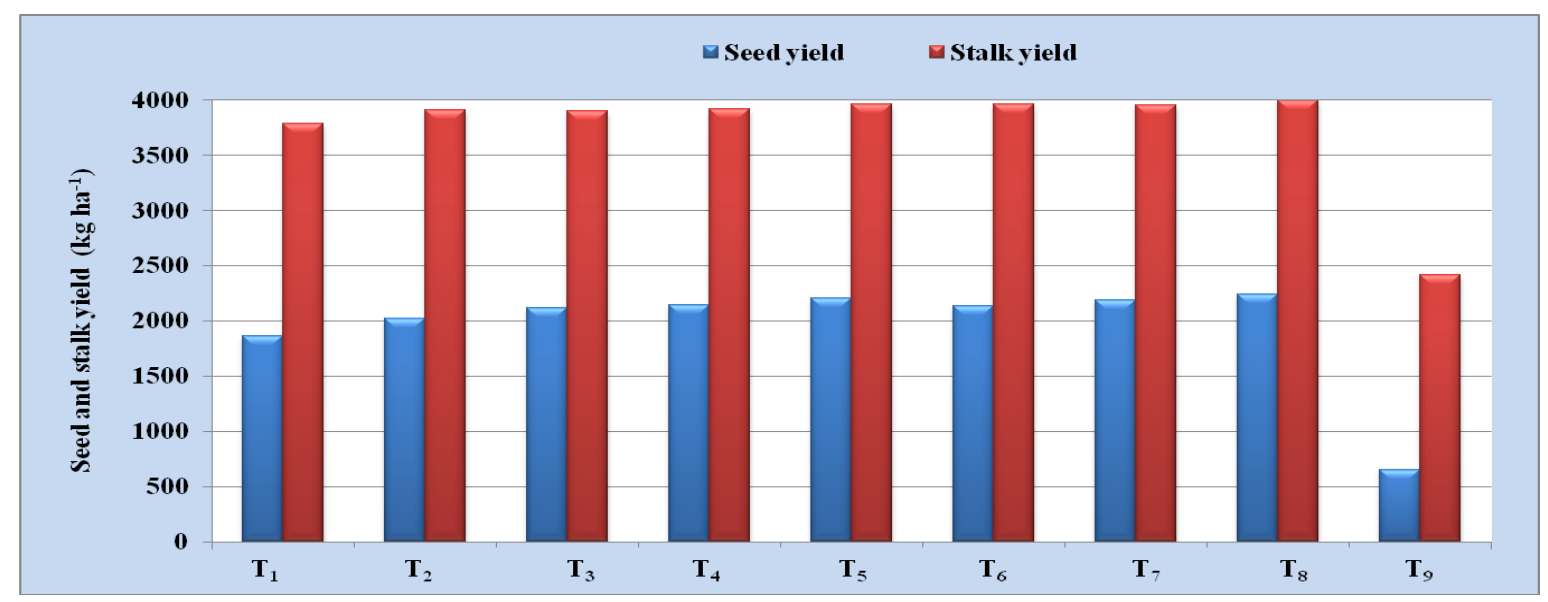

Fig.1 Effect of foliar nutrition of micronutrient mixture on seed and stalk yield of sunflower

$\mathrm{T}_{1}$ : RDF (NPK @ 90:90:60 and Gypsum @ $100 \mathrm{~kg} \mathrm{ha}^{-1}$ ), $\mathrm{T}_{2}: \mathrm{T}_{1}+\mathrm{ZnSO}_{4} @ 10 \mathrm{~kg} \mathrm{ha}^{-1}$ soil application, $\mathrm{T}_{3}: \mathrm{T}_{1}+$ Foliar spray of Grade-1 micronutrient mixture @ $2.5 \mathrm{ml} \mathrm{L}^{-1}$ of water, $\mathrm{T}_{4}: \mathrm{T}_{1}+$ Foliar spray of Grade-1 micronutrient mixture @ $5 \mathrm{ml} \mathrm{L}^{-1}$ of water, $\mathrm{T}_{5}: \mathrm{T}_{1}+$ Foliar spray of Grade-1 micronutrient mixture @ $10 \mathrm{ml} \mathrm{L}^{-1}$ of water, $\mathrm{T}_{6}: \mathrm{T}_{2}+$ Foliar spray of Grade-1 micronutrient mixture @ $2.5 \mathrm{ml} \mathrm{L}^{-1}$ of water, $\mathrm{T}_{7}: \mathrm{T}_{2}+$ Foliar spray of Grade-1 micronutrient mixture@ $5 \mathrm{ml} \mathrm{L}^{-1}$ of, water, $\mathrm{T}_{8}: \mathrm{T}_{2}+$ Foliar spray of Grade-1 micronutrient mixture @ $10 \mathrm{ml} \mathrm{L}^{-1}$ of water, $\mathrm{T}_{9}$ : Absolute control.

Note- Foliar sprayof micronutrient mixture was done at 30, 45 and 60 DAS. 
Table.2 Effect of foliar nutrition of micronutrient mixture on oil content, oil yield, protein content and protein yield of sunflower seeds

\begin{tabular}{|c|c|c|c|c|}
\hline Treatments & Oil (\%) & Protein (\%) & Oil yield $\left(\mathrm{kg} \mathrm{ha}^{-1}\right)$ & Protein yield $\left(\mathrm{kg} \mathrm{ha}^{-1}\right)$ \\
\hline $\mathbf{T}_{1}$ & 33.10 & 13.63 & 615 & 253 \\
\hline $\mathbf{T}_{2}$ & 33.37 & 14.30 & 675 & 289 \\
\hline $\mathbf{T}_{\mathbf{3}}$ & 33.03 & 15.10 & 700 & 320 \\
\hline $\mathbf{T}_{4}$ & 33.37 & 15.23 & 716 & 327 \\
\hline $\mathbf{T}_{5}$ & 34.73 & 16.27 & 764 & 358 \\
\hline $\mathbf{T}_{6}$ & 33.40 & 15.70 & 712 & 335 \\
\hline $\mathbf{T}_{7}$ & 34.07 & 16.13 & 744 & 352 \\
\hline $\mathbf{T}_{8}$ & 35.37 & 17.37 & 793 & 389 \\
\hline $\mathbf{T}_{9}$ & 32.87 & 12.30 & 536 & 131 \\
\hline S.Em. \pm & 0.83 & 0.38 & 6.19 & 7.76 \\
\hline C.D.@ 5\% & NS & 1.15 & 18.55 & 23.28 \\
\hline
\end{tabular}

$\mathrm{T}_{1}$ : RDF (NPK @ 90:90:60 and Gypsum @ $100 \mathrm{~kg} \mathrm{ha}^{-1}$ ), $\mathrm{T}_{2}: \mathrm{T}_{1}+\mathrm{ZnSO}_{4} @ 10 \mathrm{~kg} \mathrm{ha}^{-1}$ soil application, $\mathrm{T}_{3}: \mathrm{T}_{1}+$ Foliar spray of Grade-1 micronutrient mixture @ $2.5 \mathrm{ml} \mathrm{L}^{-1}$ of water, $\mathrm{T}_{4}: \mathrm{T}_{1}+$ Foliar spray of Grade-1 micronutrient mixture @ $5 \mathrm{ml} \mathrm{L}^{-1}$ of water, $\mathrm{T}_{5}: \mathrm{T}_{1}+$ Foliar spray of Grade-1 micronutrient mixture @ $10 \mathrm{ml} \mathrm{L}^{-1}$ of water, $\mathrm{T}_{6}: \mathrm{T}_{2}+$ Foliar spray of Grade-1 micronutrient mixture @ $2.5 \mathrm{ml} \mathrm{L}^{-1}$ of water, $\mathrm{T}_{7}: \mathrm{T}_{2}+$ Foliar spray of Grade-1 micronutrient mixture@ $5 \mathrm{ml} \mathrm{L}^{-1}$ of, water, $\mathrm{T}_{8}: \mathrm{T}_{2}+$ Foliar spray of Grade-1 micronutrient mixture @ $10 \mathrm{ml} \mathrm{L}^{-1}$ of water, $\mathrm{T}_{9}$ : Absolute control.

Note- Foliar sprayof micronutrient mixture was done at 30, 45 and 60 DAS.

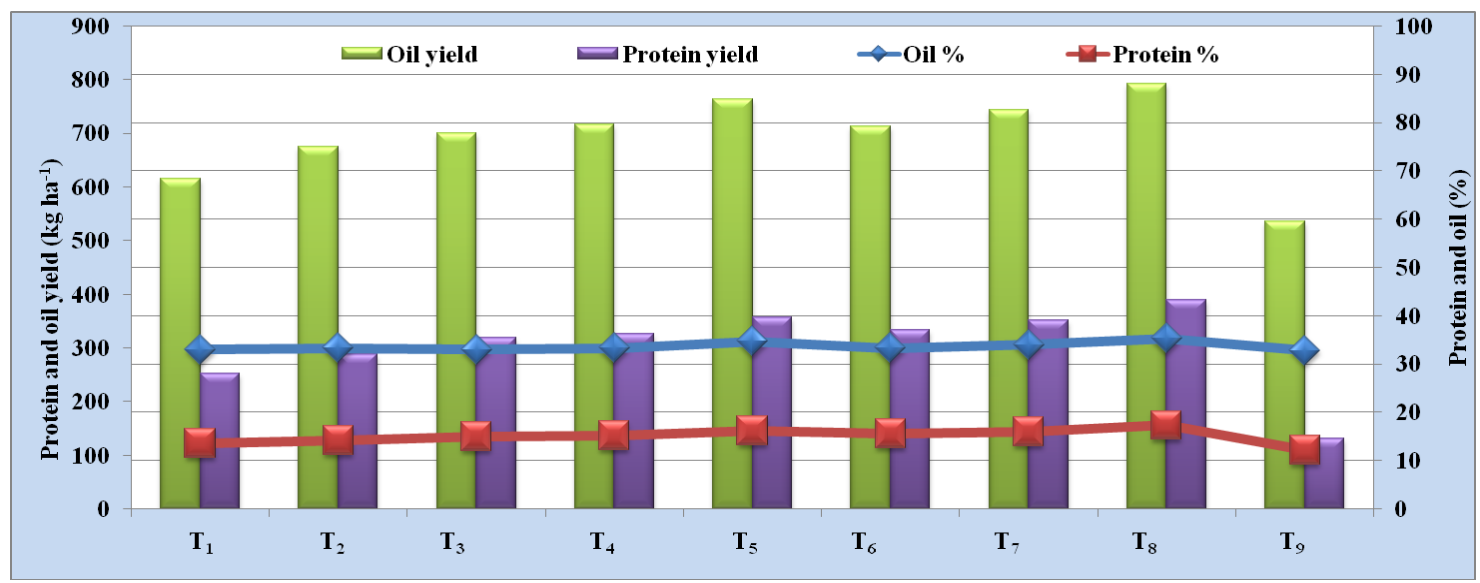

Fig.2 Effect of foliar nutrition of micronutrient mixture on quality parameters of sunflower

$\mathrm{T}_{1}$ : RDF (NPK @ 90:90:60 and Gypsum @ $100 \mathrm{~kg} \mathrm{ha}^{-1}$ ), $\mathrm{T}_{2}: \mathrm{T}_{1}+\mathrm{ZnSO}_{4} @ 10 \mathrm{~kg} \mathrm{ha}^{-1}$ soil application, $\mathrm{T}_{3}: \mathrm{T}_{1}+$ Foliar spray of Grade-1 micronutrient mixture @ $2.5 \mathrm{ml} \mathrm{L}-1$ of water, $\mathrm{T}_{4}: \mathrm{T}_{1}+$ Foliar spray of Grade-1 micronutrient mixture @ $5 \mathrm{ml} \mathrm{L}^{-1}$ of water, $\mathrm{T}_{5}: \mathrm{T}_{1}+$ Foliar spray of Grade-1 micronutrient mixture @ $10 \mathrm{ml} \mathrm{L}{ }^{-1}$ of water, $\mathrm{T}_{6}: \mathrm{T}_{2}+$ Foliar spray of Grade-1 micronutrient mixture @ $2.5 \mathrm{ml} \mathrm{L}^{-1}$ of water, $\mathrm{T}_{7}: \mathrm{T}_{2}+$ Foliar spray of Grade-1 micronutrient mixture @ $5 \mathrm{ml} \mathrm{L}^{-1}$ of, water, $\mathrm{T}_{8}: \mathrm{T}_{2}+$ Foliar spray of Grade-1 micronutrient mixture @ $10 \mathrm{ml} \mathrm{L}^{-1}$ of water, $\mathrm{T}_{9}$ : Absolute control.

Note- Foliar sprayof micronutrient mixture was done at 30, 45 and 60 DAS. 
Table.3.Effect of foliar nutrition of micronutrient mixture on economics of sunflower cultivation

\begin{tabular}{|l|c|c|c|c|}
\hline & Gross returns(Rs.) & Cost of cultivation(Rs.) & $\begin{array}{c}\text { Net } \\
\text { profit(Rs.) }\end{array}$ & B C ratio \\
\hline $\mathbf{T}_{\mathbf{1}}$ & 65680 & 30584 & 35096 & 2.15 \\
\hline $\mathbf{T}_{\mathbf{2}}$ & 71513 & 31134 & 40379 & 2.30 \\
\hline $\mathbf{T}_{\mathbf{3}}$ & 74942 & 30929 & 44013 & 2.42 \\
\hline $\mathbf{T}_{\mathbf{4}}$ & 75931 & 31275 & 44656 & 2.43 \\
\hline $\mathbf{T}_{\mathbf{5}}$ & 77805 & 31330 & 46475 & 2.48 \\
\hline $\mathbf{T}_{\mathbf{6}}$ & 75437 & 31200 & 44237 & 2.42 \\
\hline $\mathbf{T}_{\mathbf{7}}$ & 77275 & 31400 & 45875 & 2.46 \\
\hline $\mathbf{T}_{\mathbf{8}}$ & 79290 & 31550 & 47740 & 2.51 \\
\hline $\mathbf{T}_{\mathbf{9}}$ & 22978 & 18852 & 4126 & 1.22 \\
\hline
\end{tabular}

$\mathrm{T}_{1}$ : RDF (NPK @ 90:90:60 and Gypsum @ $100 \mathrm{~kg} \mathrm{ha}^{-1}$ ), $\mathrm{T}_{2}: \mathrm{T}_{1}+\mathrm{ZnSO}_{4} @ 10 \mathrm{~kg} \mathrm{ha}^{-1}$ soil application, $\mathrm{T}_{3}: \mathrm{T}_{1}+$ Foliar spray of Grade-1 micronutrient mixture @ $2.5 \mathrm{ml} \mathrm{L}^{-1}$ of water, $\mathrm{T}_{4}: \mathrm{T}_{1}+$ Foliar spray of Grade-1 micronutrient mixture @ $5 \mathrm{ml} \mathrm{L}^{-1}$ of water, $\mathrm{T}_{5}: \mathrm{T}_{1}+$ Foliar spray of Grade-1 micronutrient mixture @ $10 \mathrm{ml} \mathrm{L}^{-1}$ of water, $\mathrm{T}_{6}: \mathrm{T}_{2}+$ Foliar spray of Grade-1 micronutrient mixture @ $2.5 \mathrm{ml} \mathrm{L}^{-1}$ of water, $\mathrm{T}_{7}: \mathrm{T}_{2}+$ Foliar spray of Grade-1 micronutrient mixture@ $5 \mathrm{ml} \mathrm{L}^{-1}$ of, water, $\mathrm{T}_{8}: \mathrm{T}_{2}+$ Foliar spray of Grade-1 micronutrient mixture @ $10 \mathrm{ml} \mathrm{L}^{-1}$ of water, $\mathrm{T}_{9}$ :

Absolute control.

Note- Foliar spray of micronutrient mixture was done at 30, 45 and 60 DAS.

\section{Quality parameters}

\section{Oil content and oil yield}

$\mathrm{T}_{8}: \mathrm{RDF}+\mathrm{FYM} @ 8 \mathrm{tha}^{-1}+\mathrm{ZnSO}_{4} @ 10 \mathrm{~kg}$ $\mathrm{ha}^{-1}+$ foliar spray of micronutrient mixture @ $10 \mathrm{ml} \mathrm{L}^{-1}$ has recorded highest oil content $(35.37 \%)$ and oil yield $\left(793 \mathrm{~kg} \mathrm{ha}^{-1}\right)$ and it is on par with the $\mathrm{T}_{5}$ : RDF + FYM @ $8 \mathrm{tha}^{-1}+$ foliar spray of micronutrient mixture @ $10 \mathrm{ml}$ $\mathrm{L}^{-1}$, it is superior over RDF and absolute control(Table 2 and Fig 2).

This might be due to zinc and iron fertilization that leads to proper functioning of many enzymes involved in the formation of glucosinolates, glucosides and sulphydrillinkage, activation of enzymes which aids in biochemical reaction within the plant which helps in Biosynthesis of oil. This might have resulted in higher oil content compared to control.
However, there is no significant difference in the oil content statistically, but highest oil yield was recorded in the $\mathrm{T}_{8}$ : RDF + FYM @ $8 \mathrm{tha}^{-1}+\mathrm{ZnSO}_{4} @ 10 \mathrm{~kg} \mathrm{ha}^{-1}+$ foliar spray of micronutrient mixture@ $10 \mathrm{ml} \mathrm{L}^{-1}\left(793 \mathrm{~kg} \mathrm{ha}^{-}\right.$ ${ }^{1}$ ) which is due to the higher seed yield and oil content produced in the treatment $\left(\mathrm{T}_{8}\right)$. Lowest oil yield recorded in the control treatment. The above result is in agreement with the findings of Raghavendra et al.(2013).

\section{Protein content and protein yield}

$\mathrm{T}_{8}: \mathrm{RDF}+\mathrm{FYM} @ 8 \mathrm{tha}^{-1}+\mathrm{ZnSO}_{4} @ 10 \mathrm{~kg}$ $\mathrm{ha}^{-1}+$ foliar spray of micronutrient mixture@ $10 \mathrm{ml} \mathrm{L}^{-1}$ has recorded highest protein content $(17.37 \%)$ and protein yield $\left(389.58 \mathrm{~kg} \mathrm{ha}^{-}\right.$ ${ }^{1}$ )and superior over RDF and absolute control(Table 2 and Fig 2). This may be attributed to the role of $\mathrm{Fe}$ in nitrogen assimilation and $\mathrm{Zn}$ in synthesis of IAA which is component of enzymes for protein synthesis (Seyedeh et al., 2017 and 
Roghayyeh et al., 2018).

\section{Economics of sunflower cultivation}

Highest gross returns (C.79290 ha $\left.{ }^{-1}\right)$, net returns $\left(\mathrm{C} .47740 \mathrm{ha}^{-1}\right)$ and $\mathrm{B}: \mathrm{C}$ ratio $(2.51)$ was recorded with application of $\mathrm{T}_{8}: \mathrm{RDF}+$ FYM@8 tha ${ }^{-1}+\mathrm{ZnSO}_{4} @ 10 \mathrm{~kg} \mathrm{ha}^{-1}+$ foliar spray of micronutrient mixture @ $10 \mathrm{ml} \mathrm{L}^{-1}$ compared to RDF and all other treatments(Table 3). This was attributed to the higher seed yield and highest gross returns. The results are in conformity with the findings of Arjun Sharma et al., (2009).

From this study it can be concluded that to get higher yield and net profit, $\mathrm{B}: \mathrm{C}$ ratio, it is advised to follow $\left(\mathrm{T}_{8}\right)$ soil application of $\mathrm{ZnSO}_{4} @ 10 \mathrm{~kg} \mathrm{ha}^{-1}$ with foliar application of Grade-1 micronutrient mixture @ $10 \mathrm{ml}$ per litre water along with RDF (90:90:60 and gypsum @100 kg NPK ha ${ }^{-1}$ ) and FYM @ 8 t $\mathrm{ha}^{-1}$.

\section{References}

Arjun Sharma, Anil Kumar, Dharmaraju, P. S. and Basavaraj, K., 2009, Response of safflower to organic manure, inorganic fertilizer and micronutrients.Karnataka J. Agric. Sci., 23(4): 883-886.

Chowdhary, A. R., PrabhakaraSetty and Nagarathna T. K., 2010, Growth and yield of sunflower as influenced by micronutrients application in alfisols. Karnataka J. Agric. Sci., 23(3): 495496.

Ebrahimian, E. and Ahmad Bybordi, 2011,
Effect of iron foliar fertilization on growth, seed and oil yield of sunflower grown under different irrigation regimes. Middle-East J. Sci. Res., 9(5): 621-627.

Kirana Kumara., Narayana Rao, K., Veeresh, H., Ashok Kumar Gaddi. and Channabasavanna, A. S., 2019 Effect of foliar application of micronutrient mixture on yield, quality and major nutrient uptake by safflower. Int. J. Chem. Studies., 7(5): 4551-4557

Muhammad Anjum, F., Nadeem, M., Issa Khan, M. and Hussain, S., 2012. Nutritional and therapeutic potential of sunflower seeds: a review. British Food Journal, 114(4) : 544-552.

Raghavendra, Bellakki, M. A. andBudihal, (2013) Response of sunflower (Helianthus annuusL.) to zinc and iron fertilization under irrigation.J. Eco.Environ. Cons., 21: 485-488.

Ramesh Kumar, B., 2008, Influence of sulphur and boron on growth and yield of sunflower (Helianthus annuusL.).M $S c$ (Agri)thesis submitted to ANGRAU.

Roghayyeh, S., Mohammad, S. and Bahram, 2018, The effect of ferrous nano-oxide particles on physiological traits and nutritional compounds of soybean (Glycine max L.) Seed.Anal.Brazilian Academy. Sci., 90(1): 485-494.

Seyedeh, M., MajidMajidian and SeyyedMohammadrezaEhteshami, 2017, Evaluation of iron and zinc foliar and soil application on quantitative and qualitative characteristics of two soybean cultivars. IIOB J.,8(3): 1-7.

\section{How to cite this article:}

Narayana Rao. K, E. Rajath, and Kirana Kumara. 2020. Yield, Quality Parameters and Economics of Sunflower (Helianthus annuus L.) as Influenced by Micronutrient Mixture Foliar Application. Int.J.Curr.Microbiol.App.Sci. 9(01): 1999-2005.

doi: https://doi.org/10.20546/ijcmas.2020.901.226 